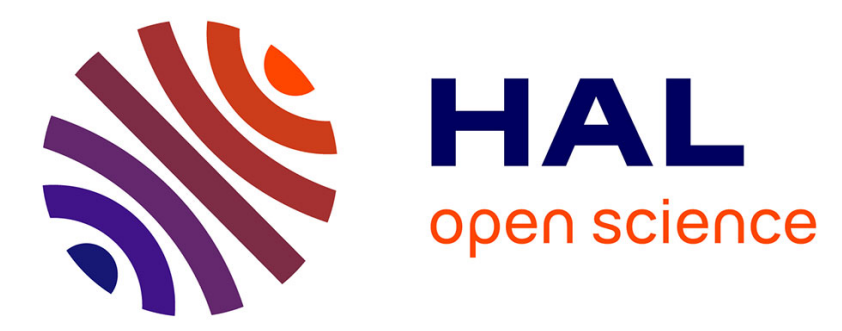

\title{
Long-term population fluctuations of the exotic New Zealand mudsnail Potamopyrgus antipodarum and its introduced aporocotylid trematode in northwestern France
}

Claudia Gérard, Maxime Hervé, Ryan Hechinger

\section{To cite this version:}

Claudia Gérard, Maxime Hervé, Ryan Hechinger. Long-term population fluctuations of the exotic New Zealand mudsnail Potamopyrgus antipodarum and its introduced aporocotylid trematode in northwestern France. Hydrobiologia, 2018, 817 (1), pp.253-266. 10.1007/s10750-017-3406-x . hal01827551

\section{HAL Id: hal-01827551}

\section{https://hal-univ-rennes1.archives-ouvertes.fr/hal-01827551}

Submitted on 3 Sep 2018

HAL is a multi-disciplinary open access archive for the deposit and dissemination of scientific research documents, whether they are published or not. The documents may come from teaching and research institutions in France or abroad, or from public or private research centers.
L'archive ouverte pluridisciplinaire HAL, est destinée au dépôt et à la diffusion de documents scientifiques de niveau recherche, publiés ou non, émanant des établissements d'enseignement et de recherche français ou étrangers, des laboratoires publics ou privés. 


\section{Long-term population fluctuations of the exotic New Zealand mudsnail Potamopyrgus antipodarum and its introduced aporocotylid trematode in northwestern France}

Claudia Gérard, $1 \square$

Phone 332-23-23-50-37

Email claudia.gerard@univ-rennes1.fr

Maxime Hervé, 2

Ryan F. Hechinger, 3

${ }^{1}$ Ecosystèmes, Biodiversité, Evolution (UMR ECOBIO 6553), Université de Rennes, 35042 Rennes, France

2 IGEPP, Université de Rennes 1, Avenue du Général Leclerc, 35042 Rennes, France

3 Scripps Institution of Oceanography-Marine Biology Research

Division, University of California, San Diego, La Jolla, CA, 92093 USA

Received: 30 March 2017 / Accepted: 4 October 2017

\section{Abstract}

Long-term studies of invasive populations are rare, which is unfortunate because important aspects of their dynamics may only be detected over long term. For instance, invasive populations can experience substantial population declines, or even crashes, sometime after their introduction and invasion. Potamopyrgus antipodarum (Caenogastropoda) is a successful invader, and is rarely parasitized in introduced areas. In France, the snail is parasitized as first intermediate host by only one trematode species (Aporocotylid sp. I), native to the snail's home range, New Zealand. Here, we examined the dynamics of the molluscan assemblage in a French stream 
on a 14-year interval (2000-2004 and 2009-2013), focusing on this introduced host-parasite association. Overall, $P$. antipodarum was numerically dominant $(90.80 \%)$ among molluscs, also including sphaeriid clams $(9.12 \%)$ and pulmonate snails $(0.08 \%)$. However, during the last monitoring period, we found a substantial population decline of $P$. antipodarum, potentially driven by environmental change, such as decreased water temperature and depth, and possibly competitive interactions with sphaeriids, which became numerically dominant (56.34\%). P. antipodarum was the only mollusc found infected and only by Aporocotylid sp. I. Interestingly, despite low monthly prevalence (from 0 to $1.52 \%$ ) and snail host population decline, the P. antipodarum-aporocotylid relationship appeared to be persistent over time.

\section{Keywords}

Invasive Potamopyrgus antipodarum

Introduced aporocotylid

Long-term population dynamics

Decline

Abiotic parameters

Sphaeriids

\section{Electronic supplementary material}

The online version of this article (doi:10.1007/s10750-017-3406-x) contains supplementary material, which is available to authorized users.

Guest editors: John E. Havel, Sidinei M. Thomaz, Lee B. Kats, Katya E. Kovalenko \& Luciano N. Santos / Aquatic Invasive Species II

\section{Introduction}

Long-term studies of species invasions are relatively rare. This is unfortunate, because although invasive species do undergo periods of rapid population growth and spread [when we deem them "invasive" (Kolar \& Lodge, 2001)], they can then strongly fluctuate in abundance over time, and sometimes even spontaneously collapse (Simberloff \& Gibbons, 2004; Strayer et al., 2006; Simberloff, 2013 for reviews). Hence, the preponderance of short-term studies of introduced species will not provide the full understanding of the impacts of invasive species. The demographic success of invasive species can be affected 
by many factors such as abiotic stresses due to environmental change (e.g., drought, pollution), impacts of parasitism (by parasites introduced after the host introduction and/or native parasites acquired after introduction), and other interactions (Simberloff \& Gibbons, 2004; Strayer et al., 2006; Simberloff, 2013 for reviews).

The freshwater snail, Potamopyrgus antipodarum (Gray, 1843) (Caenogastropoda), is a globally invasive species, which is a member of the largely Australasian family Tateidae [previously a subfamily of the Hydrobiidae, but now recognized as being a separate family (Zielske et al., 2011; Wilke et al., 2013)]. Native to New Zealand, P. antipodarum has invaded streams and lakes of most of the world's continents including Australia, Europe, America, and Asia (Alonso \& Castro-Díez, 2012; Collado, 2014). Its introduction on these different continents likely has multiple independent origins, but has involved only a small number of parthenogenetic clones (e.g., Hughes, 1996; Jacobsen \& Forbes, 1997; Städler et al., 2005; Hoy et al., 2012). In Europe, only two haplotypes have been reported to date: "t" and "z." The most widely distributed is haplotype $t$, which appears to be a generalist in fresh waters, whereas haplotype $\mathrm{z}$ is restricted to brackish waters (Städler et al., 2005). As for many invasive species, the successful spread of $P$. antipodarum is at least partly explained by inadvertent human introductions, but also by the snail's mode of reproduction (i.e., ovoviviparity and parthenogenesis), wide physiological tolerances (e.g., euryhalinity), efficient dispersal, and enemy release (predators, parasites) (Alonso \& Castro-Díez, 2008, 2012 for reviews). In its native range, $P$. antipodarum is first intermediate host for as many as 20 species of highly host-specific trematodes (Hechinger, 2012), which, as parasitic castrators, generally can substantially impact host populations (e.g., Lafferty, 1993; Gérard, 1997, 2001; Negovetich \& Esch, 2008). In contrast, in Europe, populations are rarely parasitized. Previous studies in France and Poland revealed that $P$. antipodarum was infected as first intermediate host by only a single trematode species and at very low levels $(\leq 0.48 \%$ in France, $0.007 \%$ in Poland) (-Gérard \& Dussart, 2003; Gérard \& Le Lannic, 2003; Gérard et al., 2003; Zbikowski \& Zbikowska, 2009). This trematode was reported for the first time in 1999 in western France (Gérard et al., 2003), where $P$. antipodarum was first recorded in 1912 (Lucas, 1965). DNA sequence analyses indicate that the trematode from French $P$. antipodarum corresponds to Aporocotylid sp. I (sensu Hechinger, 2012), a New Zealand blood fluke with a two-host life cycle that infects fishes as final hosts (Gérard et al., 
2017). Both in New Zealand and in Europe, the average prevalence of Aporocotylid sp. I in P. antipodarum is very low (0.07\%), suggesting that this trematode probably does not regulate native or introduced snail host populations (Gérard et al., 2017).

Here, we investigate the long-term population dynamics of $P$. antipodarum and its aporocotylid parasite in a French stream over a 14-year period, with intensive sampling during 2000-2004 [just after the first record in 1999 of the parasite in the same region (Gérard et al., 2003)] and 2009-2013 (10 years after). We had three aims. First, we sought to better understand temporal fluctuations of the introduced population of $P$. antipodarum in relation with abiotic and biotic conditions. Therefore, we examine the temporal fluctuations of two major abiotic parameters; water temperature, which is crucial for ectotherms such as molluscs and which can correlate with other physicochemical parameters, and depth, which reflects the availability of habitat/space resources. We also examine the long-term dynamics of the whole molluscan assemblage, which may include potential competitors with the invasive snail. Second, we wished to observe whether there was a delayed regulation or even a crash of the invasive mudsnail following its introduction. Third, we sought to examine details of parasitism by the introduced aporocotylid parasite in the P. antipodarum population. Gérard et al. (2017) presented limited information concerning the parasite's prevalence, using pooled samples from this same dataset. Here, we reported higher-resolution details of the prevalence of Aporocotylid sp. I in P. antipodarum throughout the entire 14-year time period, and we examined the occurrence of parasitic trematodes (including Aporocotylid sp. I) in the rest of the molluscan assemblage.

\section{Materials and methods}

\section{Study site}

We conducted monitoring in a fourth-order oligotrophic stream (Le Petit Hermitage, in Ille-et-Vilaine, eastern Brittany, France, $48^{\circ} 32^{\prime} \mathrm{N}, 1^{\circ} 34^{\prime} \mathrm{W}$ ) draining a 10 ha-catchment area in a riparian wetland at an altitude of ca. $20 \mathrm{~m}$ above sea level (see Clément et al., 2002; Lefebvre et al., 2004; Gruau et al., 2004 for site details). Stream flow is characterized by a base-flow period from June to November (mean monthly discharge $\leq 40 \mathrm{~L} \mathrm{~s}^{-1}$ ), and a high-flow period from December to May $\left(>40 \mathrm{~L} \mathrm{~s}^{-1}\right)$. Stream substratum is primarily schist, consisting mainly of fine gravel and coarse sand. We 
measured physicochemical variables in May 2003 (Supplementary Table). Water had medium calcium levels $\left(10-40 \mathrm{mg} / \mathrm{Ca}^{2+}\right)$, known to provide the most favorable conditions for freshwater molluscs (Dussart, 1976, 1977).

\section{Sample collection and measurements}

To ensure a standard search effort, the same person (CG) sampled molluscs at 62 different dates on a 14-year interval during two broad time periods. The early period included June 2000-September 2004, with monthly samples collected in June 2000-June 2001, March 2002-June 2002, September 2002, March-May 2003, May 2004, and September 2004. The later period included April 2009-May 2013, with monthly samples in April 2009-March 2012, and March 2013-May 2013. On each occasion, we measured water temperature $\left({ }^{\circ} \mathrm{C}\right)$ and maximum water depth $(\mathrm{cm})$. Then, we trawled a pond-net (nylon mesh: $1 \mathrm{~mm}$, square aperture: $0.5 \times 0.5 \mathrm{~m}$ ) from the surface sediment through the water column for three minutes along a $20 \mathrm{~m}$ long $\times 2 \mathrm{~m}$ wide area, as in previous studies (Blanc \& Gérard, 2001; Gérard \& Dussart, 2003; Gérard et al., 2009). We carefully examined the contents in tap water in the laboratory, and we counted and identified all the molluscs, following Glöer \& Meier-Brook (1994), to the species level for gastropods and to the family level for bivalves. We measured the shell size of each gastropod to the nearest $0.1 \mathrm{~mm}$, but we only measured bivalve size in March 2003, May 2004, and September 2004. We dissected each mollusc under a stereoscopic microscope to detect infection by larval trematodes (sporocysts or rediae, and cercariae) and to record sex for gonochoristic species (i.e., P. antipodarum). When present, parasites were observed alive under light glass coverslip pressure using bright-field and phase-contrast microscopy.

We dissected females of $P$. antipodarum with shell height $\geq 2.5 \mathrm{~mm}$ to count the number of brooded embryos in March, April, and May 2002 (1008 females), in May 2004 (69), and in March, April, and May 2013 (37).

Fecundity was not investigated in females $<2.5 \mathrm{~mm}$ because the smallest size of gravid females from the stream was previously shown to be about $3.0 \mathrm{~mm}$ (Gérard \& Poullain, 2005).

We noted the general occurrence of other macroinvertebrates in the pond-net contents without specific identification in March-April 2002, September 2002, and March-April-May 2013; no obvious changes occurred between dates. Macroinvertebrates were classified to the following taxonomic groups: Erpobdellidae, Glossiphoniidae, Lumbriculidae, Conchostracea, Gammaridae, 
Ephemeroptera, Trichoptera, Zygoptera, Heteroptera, Coleoptera, and Chironomidae. We also recorded some vertebrates throughout the whole 14-year study, including one lamprey Lampetra planeri (Bloch, 1784) (Petromyzontidae) and three juvenile stone loaches Nemacheilus barbatulus (Linnaeus, 1758) (Balitoridae) in September 2002, and one yellow eel Anguilla anguilla (Linnaeus, 1758) (Anguillidae) in September 2009. AQ1

\section{Statistical analysis}

We report central tendencies as the mean $\pm 95 \%$ confidence interval (CI). We describe parasitism by prevalence (number of hosts infected with a particular parasite species/number of examined hosts) (Bush et al., 1997). For prevalence, we calculated CI using the score method (Newcombe, 1998).

We performed analyses using R software (R Core Team, 2014). We analyzed temporal variation of the $P$. antipodarum population using a linear model (LM) based on generalized least squares (GLS) to take into account temporal autocorrelation (autoregressive process of order 1) [R package nlme (Pinheiro et al., 2016 Please, replace "2016" by "2017". )]. The number of individuals was $\log _{\mathrm{e}}$ transformed, and the independent variables were time [number of months since the first sampling date, i.e., from 0 (June 2000) to 139 (March 2012)], monitoring period (June 2000-June 2001, March 2002-September 2004, April 2009-March 2012), water depth, and the interaction between time and monitoring period. The monitoring period of March 2013-May 2013 (3 months) was not included in analyses because it is composed of only three data points. Water temperature was not considered because preliminary analyses showed that it was clearly correlated with time (Spearman correlation: $r=-0.398, S=55,536, P=0.001$ ) and water depth (Spearman correlation: $r=-0.456, S=57,817, P<0.001)$, whereas water depth was not correlated with time (Spearman correlation: $r=-0.142, S=45,356$, $P=0.270$ ). We used a Wald test to assess significance of each term of the model and least square means (LSMeans) for post hoc analyses [R package lsmeans (Lenth, 2016)]. When there was a significant interaction between time and monitoring period, we tested the slope of the P. antipodarum-time relationship against the null value for each monitoring period. When there was a significant effect of monitoring period, we computed the LSMean abundance and $95 \%$ CI of $P$. antipodarum at the middle point of each monitoring period in order to control for possible trends over time within periods. The three CI were Bonferroni-adjusted and examined for overlap. 
We analyzed the abundance of Sphaeriidae ( $\log _{\mathrm{e}}$-transformed) in the exact same way as for the abundance of $P$. antipodarum. We tested the general relationship between these two abundances ( $P$. antipodarum and Sphaeriidae) independently of the time period using a Pearson correlation test.

Due to the high proportion of zeroes and the very low non-zero values in parasite prevalence and abundance data, it was not possible to fit a proper model on these data, and so we performed no statistical analysis.

We analyzed the fecundity of $P$. antipodarum using a likelihood-ratio test based on a generalized linear model (family: negative binomial, link: $\log _{\mathrm{e}}$ ) where the independent variables were the female's size treated as an ordinal factor with five levels: $2.5-2.99,3.0-3.49,3.5-3.99,4.0-4.49$, and 4.5-4.99 mm), sampling year (2002, 2004, and 2013), month nested in year (March, April, and May), and the female size $\times$ year interaction. We tested the relationship between the mean monthly fecundity and the total number of $P$. antipodarum sampled the same months using a Pearson correlation test.

We compared mean monthly water temperature between monitoring periods (June 2000-June 2001, March 2002-September 2004, April 2009-March 2012) using an ANOVA based on an LM. We chose mean monthly temperature in order to take into account that temperature was not consistently monitored among the three periods. We applied the same procedure to water depth.

Differences were considered statistically significant at $P \leq 0.05$.

\section{Results}

\section{Temporal fluctuations of temperature and depth}

Temperature, which varied from 0 to $17^{\circ} \mathrm{C}$ during the whole study, was different between the three monitoring periods according to the LM model, $\left(F_{2,15}=27.93, P<0.0001\right)$ (Fig. 1a). Specifically, temperature was significantly lower during the last monitoring period (April 2009-March $2012,6.4 \pm 0.4^{\circ} \mathrm{C}$ ) compared to both the first (June 2000-June 2001, $9.0 \pm 0.4^{\circ} \mathrm{C}$ ) and second periods (March 2002-September 2004,

$11.7 \pm 0.7^{\circ} \mathrm{C}$ ), and temperature was also different between these two periods (Fig. 1a). 
Fig. 1

Temporal fluctuations of (a) water temperature and (b) maximal water depth in the French stream (Le Petit Hermitage) during the three monitoring periods included in statistical analyses, i.e., June 2000-June 2001, March 2002-September 2004, and April 2009-March 2012. Full circles are observed values, empty circles are predicted values
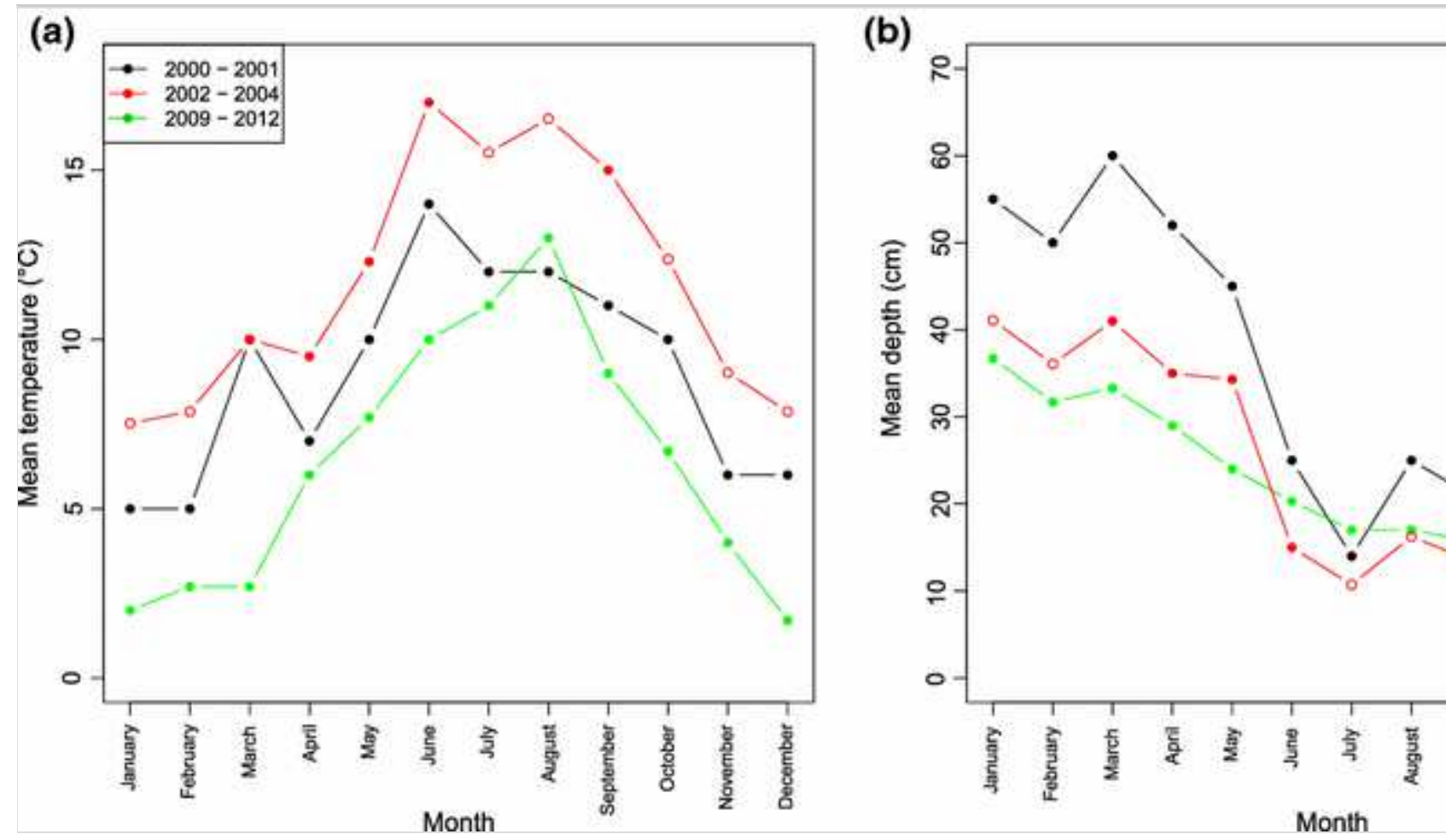

Maximal water depth, which varied from 10 to $70 \mathrm{~cm}$ during the whole study, was also different between the three monitoring periods according to the LM model $\left(F_{2,15}=15.70, P<0.0001\right)$ (Fig. $\left.1 b\right)$. Specifically, depth was significantly higher during the first period (June 2000-June 2001, $41.4 \pm 2.1 \mathrm{~cm}$ ) compared to both the second (March 2002-September 2004, $28.6 \pm 3.7 \mathrm{~cm}$ ) and third periods (April 2009-March 2012, $25.3 \pm 2.1 \mathrm{~cm}$ ), which were not different from each other (Fig. 1b).

\section{Temporal fluctuations of $P$. antipodarum and its life history characteristics}

Potamopyrgus antipodarum abundance showed strong periodicity, with positive autocorrelation being strongest at time intervals of 1-2 months and about 1 year (10-13 months). The LM-GLS model revealed no significant effect of depth on $P$. antipodarum abundance $\left(F_{1,52}=2.83, P=0.098\right)$, but a 
significant effect on abundance of time $\left(F_{1,52}=89.38, P<0.0001\right)$, monitoring period $\left(F_{2,52}=18.99, P<0.0001\right)$, and their interaction $\left(F_{2,52}=3.51, P=0.037\right)$. The mean abundance of snails was significantly different between the three monitoring periods. Indeed, it was sixfold higher during the second period [March 2002-September 2004, back-transformed LSMean (95\% CI): 1,992 (1021-3886) snails] compared to the first period [June 2000-June 2001, 319 (154-664) snails], and 87-fold higher compared to the third period [April 2009-March 2012, 23 (15-36) snails] (Fig. 2a).

Moreover, we observed a significant temporal trend of the snail population only during the first monitoring period, with a tenfold increase in population size from June 2000 to June $2001\left(t_{52}=2.42, P=0.019\right)$ (Fig. 2a). No male $P$. antipodarum was encountered.

\section{Fig. 2}

Temporal fluctuations of (a) P. antipodarum abundance ( $\log _{\mathrm{e}}$-values) and (b) Sphaeriidae abundance $\left(\log _{\mathrm{e}}\right.$-values) Please, the legend of $\mathrm{Y}$ axis has to be corrected on Fig. $2 b$ : it is the number of Sphaeriidae sampled (not P. antipodarum). in the French stream (Le Petit Hermitage) during the three monitoring periods included in statistical analyses, i.e., June 2000-June 2001, March 2002-September 2004, and April 2009-March 2012. Sample sizes are indicated in Table 2. Different letters $(a, b, c)$ in bar plots indicate statistically significant differences between monitoring periods. When a statistically significant relationship between mollusc abundance and time was found, this is represented by the corresponding regression line 

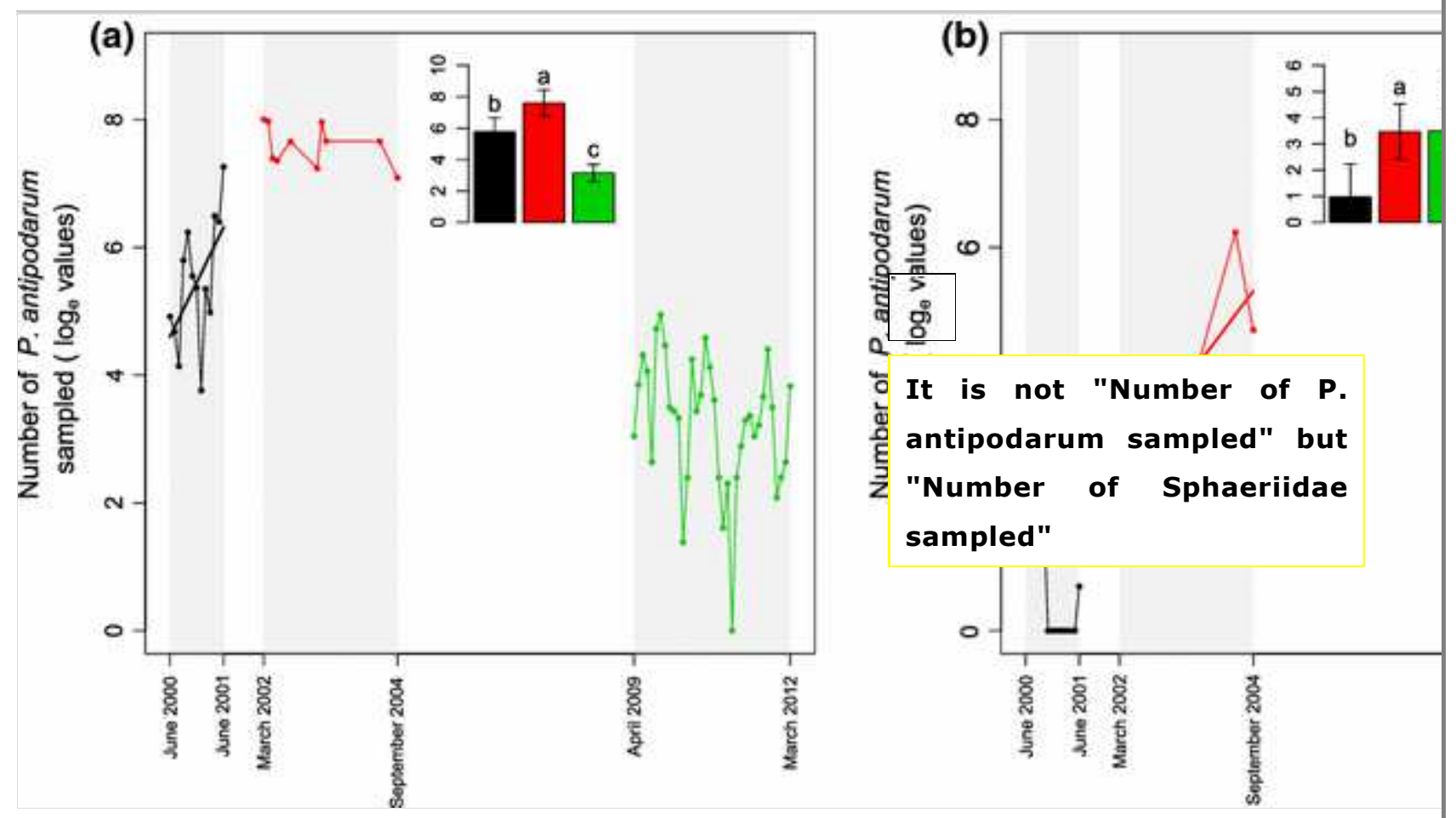

According to the GLM, the number of embryos per female significantly increased with shell size $\left(\chi^{2}=818.90, d f=4, P<0.0001\right)$, and did so similarly in each year fecundity data were taken $(2002,2004$, and 2013) $\left(\chi^{2}=10.50, d f=7, P=0.162\right)$ (Table 1$)$. The GLM also revealed a significant increase of fecundity from March to April $\left(\chi^{2}=48.24, d f=4, P<0.0001\right)$ (Table 1). Moreover, the mean number of embryos per female was significantly different between 2002, 2004, and $2013\left(\chi^{2}=10.36, d f=2\right.$, $P=0.006)$. Specifically, in 2002 and 2004, the mean embryo number per female, respectively, $15.25 \pm 0.79$ and $16.87 \pm 2.86$, was significantly lower than in 2013, i.e., $27.78 \pm 7.59$ (Table 1). Despite there being a hint that fecundity was highest when P. antipodarum density was lowest (Table 1), no correlation was found between the mean monthly fecundity and the $P$. antipodarum abundance $\left(r=-0.21, t_{5}=-0.47, P=0.657\right)$. Additionally, $P$. antipodarum populations consistently had adults (individuals $>3 \mathrm{~mm}$ ), with new snail recruitment at several points throughout the year, and two or even three generations were observed in most months but without obvious period of recruitment [Supplementary Fig. Relative size-frequency distributions from June 2000 to September 2004 (a), and from April 2009 to May 2013 (b)].

\section{Table 1}

Mean number $( \pm \mathrm{CI})$ per size class and maximal number (Max) of embryos per female of (March, April, May), 2004 (May), and 2013 (March, April, May) 


\begin{tabular}{|l|l|l|l|l|l}
\hline (mm) & March & April & May & $\begin{array}{l}\text { Mean } \\
\text { number/year }\end{array}$ & May \\
\hline $2.5-3.0$ & $0.88 \pm 0.40$ & $4.64 \pm 1.43$ & - & $2.01 \pm 0.58$ & $0.90 \pm$ \\
\hline $3.0-3.5$ & $7.11 \pm 1.01$ & $11.82 \pm 1.38$ & $9.67 \pm 12.50$ & $7.53 \pm 0.93$ & $8.60 \pm$ ( \\
\hline $3.5-4.0$ & $16.54 \pm 1.13$ & $16.05 \pm 1.97$ & $20.84 \pm 2.17$ & $17.03 \pm 0.94$ & $21.03 \pm$ \\
\hline $4.0-4.5$ & $26.68 \pm 1.96$ & $22.77 \pm 3.74$ & $34.33 \pm 1.89$ & $29.60 \pm 1.39$ & $25.33 \pm$ \\
\hline $4.5-5.0$ & - & - & $43.18 \pm 4.56$ & $43.18 \pm 4.56$ & - \\
\hline $\begin{array}{l}\text { Mean } \\
\text { number/month }\end{array}$ & $12.51 \pm 0.83$ & $12.97 \pm 1.56$ & $29.15 \pm 1.74$ & $15.25 \pm 0.79$ & $16.87 \pm$ \\
\hline $\begin{array}{l}\text { Number of Pa } \\
\text { dissected }\end{array}$ & 726 & 129 & 153 & 1,008 & 69 \\
\hline Max & 48 & 41 & 61 & 61 & 40 \\
\hline
\end{tabular}

- means that no snails were found in this size class

\section{Molluscan assemblage and overall parasite prevalence}

A total of 29,865 molluscs were collected during the study, among which $90.80 \%(27,118)$ were $P$. antipodarum. The other mollusc species corresponded to Sphaeriidae (9.13\%), a family of Bivalvia [namely, Pisidium spp. Pfeiffer, 1821 and Sphaerium corneum (Linnaeus, 1758)], and to Pulmonata $(0.07 \%)$ belonging to five families (Acroloxidae, Ancylidae, Lymnaeidae, Physidae, and Planorbidae) (Table 2). All the pulmonate snails were juveniles according to their shell size, and included 14 individuals of Planorbis planorbis (Linnaeus, 1758), two individuals of Ancylus fluviatilis Müller, 1774 and Aplexa hypnorum (Linnaeus, 1758) and one individual of Acroloxus lacustris (Linnaeus, 1758), Physa heterostropha (Say, 1817), and Radix ovata (Draparnaud, 1805). Mean species richness of gastropods (seven species in total) over the 62 sampling dates of the study was very low: $1.23 \pm 0.13$ species.

\section{Table 2}

Molluscan assemblage (total abundance, A, and relative abundance, A-\%) in the French stream Le Petit Hermitage from June 2000 to May 2013 according to the monitoring period $(\mathrm{NMS}=$ number of monthly samples per period)

\section{P. antipodarum Pulmonata Sphaeriidae}

\begin{tabular}{|l|l|l|l|l|l|l|l|}
\hline A & A $\%$ & A & A $\%$ & A & A $\%$ & Total & NMS \\
\hline
\end{tabular}




\begin{tabular}{|c|c|c|c|c|c|c|c|c|}
\hline & \multicolumn{2}{|c|}{ P. antipodarum } & \multicolumn{2}{|c|}{ Pulmonata } & \multicolumn{2}{|c|}{ Sphaeriidae } & \multirow{2}{*}{ Total } & \multirow{2}{*}{ NMS } \\
\hline & $\mathbf{A}$ & A\% & $\mathbf{A}$ & A\% & $\mathbf{A}$ & $\mathbf{A} \%$ & & \\
\hline $\begin{array}{l}\text { Jun } \\
2000-\text { Jun } \\
2001\end{array}$ & $\begin{array}{l}4,713 \\
(15)\end{array}$ & 99.45 & $4(0)$ & 0.08 & $22(0)$ & 0.46 & 4,739 & 13 \\
\hline $\begin{array}{l}\text { Mar } \\
2002-\text { Sep } \\
2004\end{array}$ & $\begin{array}{l}20,941 \\
(9)\end{array}$ & 96.23 & $\begin{array}{l}12 \\
(0)\end{array}$ & 0.06 & $\begin{array}{l}808 \\
(0)\end{array}$ & 3.71 & 21,761 & 10 \\
\hline $\begin{array}{l}\text { Apr } \\
\text { 2009-Mar } \\
2012\end{array}$ & $\begin{array}{l}1,392 \\
(1)\end{array}$ & 43.66 & $0(0)$ & 0.00 & $\begin{array}{l}1,796 \\
(0)\end{array}$ & 56.34 & 3,188 & 36 \\
\hline $\begin{array}{l}\text { Mar } \\
2013-\text { May } \\
2013\end{array}$ & $72(0)$ & 40.68 & $5(0)$ & 2.82 & $\begin{array}{l}100 \\
(0)\end{array}$ & 56.50 & 177 & 3 \\
\hline Total & $\begin{array}{l}27,118 \\
(25)\end{array}$ & 90.80 & $\begin{array}{l}21 \\
(0)\end{array}$ & 0.07 & $\begin{array}{l}2,726 \\
(0)\end{array}$ & 9.13 & 29,865 & 62 \\
\hline
\end{tabular}

See the sampling dates for each monitoring period in "Materials and methods".". Number of infected individuals is indicated in parenthesis

Despite its high overall relative abundance $(90.80 \%)$, P. antipodarum was numerically dominant only during the first broad time period (June 2000-June 2001, March 2002-September 2004) when it comprised 96.81\% of mollusc individuals. In contrast, during the second time period (April 2009-March 2012, March 2013-May 2013), P. antipodarum represented only $43.51 \%$ of all encountered molluscs, and the Sphaeriidae become the numerically dominant taxon, with 56.34\% relative abundance (Table 2). However, no significant relationship was found between the abundance of $P$. antipodarum and the abundance of Sphaeriidae (Pearson correlation: $r=0.14, t_{57}=1.11$, $P=0.272)$.

Potamopyrgus antipodarum was the only molluscan species found parasitized (Table 2) and, as reported by Gérard et al. (2017), it was only infected by the trematode species Aporocotylid sp. I, with an overall prevalence of $0.09 \%$ (CI 0.06-0.14\%). Below, we report details on the temporal fluctuations of prevalence.

\section{Temporal fluctuations of Sphaeriidae}

Sphaeriidae abundance showed strong periodicity, with positive autocorrelation being strongest at a time interval of 6 months. The LM-GLS 
model demonstrated a significant and negative effect of depth $\left(F_{2,52}=10.23\right.$, $P=0.002)$, and a significant effect of time $\left(F_{1,52}=10.49, P=0.002\right)$, monitoring period $\left(F_{2,52}=8.36, P=0.0007\right)$, and time x period interaction $\left(\left(F_{2,52}=3.82, P=0.028\right)\right.$. The abundance of Sphaeriidae was also higher during the two last monitoring periods [March 2002-September 2004, back-transformed LSMean (95\% CI): 31 (13-74) bivalves; April 2009-March 2012, 32 (16-64) bivalves] compared to the first [June 2000-June 2001, two (0-6) bivalves] (Fig. 2b). Moreover, we observed a significant temporal trend only during the second monitoring period with a 27 -fold increase of Sphaeriidae from March 2002 to September $2004\left(t_{52}=2.84, P=0.006\right)$ (Fig. 2b).

\section{Temporal fluctuations of Aporocotylid sp. I}

The monthly prevalence of Aporocotylid sp. I infecting P. antipodarum varied from $0.00 \%$ (CI $0.00-0.13 \%, n=2871$ ) in April 2003 to a maximum of $1.52 \%$ (CI $0.65-3.50 \%, n=330$ ) in September 2000 (Fig. 3). The abundance of infected $P$. antipodarum per monitoring period decreased over time, whatever the total abundance of $P$. antipodarum (Table 2). However, the overall prevalence of infection did not significantly vary between monitoring periods, given the generally overlapping $95 \% \mathrm{CI}$ calculated on the prevalence data [June 2000-June 2001 prevalence $=0.32 \%(0.19-0.52 \%)$, March 2002-September 2004 prevalence $=0.04 \%(0.02-0.08 \%)$, April 2009-May 2012 prevalence $=0.07 \%(0.01-0.41 \%)$, March-May 2013 prevalence $0 \%$ $(0.00-5.07 \%)]$.

\section{Fig. 3}

Temporal fluctuations of Aporocotylid sp. I prevalence (\%) in the French stream (Le Petit Hermitage) during the three monitoring periods included in statistical analyses, i.e., June 2000-June 2001, March 2002-September 2004, and April 2009-March 2012. Sample sizes are indicated in Table 2. Note that, despite temporal fluctuations, prevalence was always low $(\leq 1.52 \%)$ throughout the monitoring periods 


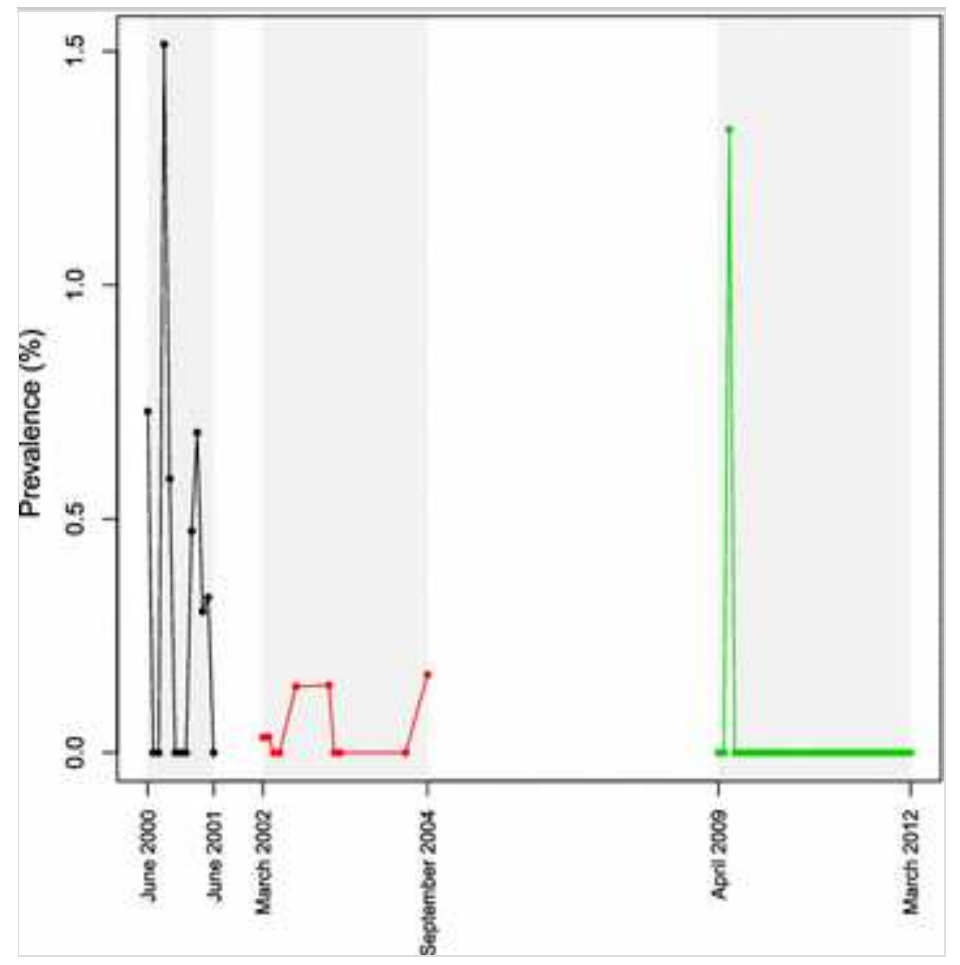

\section{Discussion}

\section{Molluscan assemblage in Le Petit Hermitage}

We recorded seven species of gastropods (the caenogastropod P. antipodarum and six pulmonates) and two taxa of bivalves belonging to Sphaeriidae in Le Petit Hermitage during the whole study. However, the diversity was very low over time (1.2 \pm 0.1 gastropod species per sampling date) as was the mean abundance of most species $(\leq 0.2 \pm 0.2$ individuals of each pulmonate species per sampling date). The molluscan assemblage in the study site was characterized by a high dominance of the exotic mudsnail P. antipodarum, especially during the period of 2000-2004 (97\%). By the period of 2009-2013, the relative abundance of $P$. antipodarum decreased to $44 \%$ of the molluscan assemblage, which was then dominated by Sphaeriidae (56\%). These cosmopolitan bivalves are very common and abundant in Europe, occurring in all types of running and still waters (Boycott, 1936; Dussart, 1979; Holopainen \& Jónasson, 1989). Interestingly, while Sphaeriidae were rare (3\%) in Le Petit Hermitage during the period of 2000-2004, they were abundant ( $\sim 50 \%$ of the molluscan assemblage) at the same time in a nearby pond (about $50 \mathrm{~m}$ away), which was connected to the stream during the flood season and where P. antipodarum has never been recorded (Blanc \& Gérard, 2001; Gérard et al., 2009; Gérard, pers. obs.). We rarely found pulmonates, all native species, in the stream during the study $(0.07 \%)$ and, when encountered, 
they were always juveniles. Most of these individuals probably originated from the above mentioned nearby pond, where most of the pulmonate species were commonly recorded and abundant (Blanc \& Gérard, 2001; Gérard et al., 2009; Gérard, pers. obs.). Environmental conditions in Le Petit Hermitage appeared unfavorable for these pulmonates compared to the pond (Blanc \& Gérard, 2001; Gérard et al., 2009), whereas they seemed to become favorable for Sphaeriidae based on their dominance during the period of 2009-2013.

\section{Temporal fluctuations of abundance and fecundity of $P$. antipodarum}

Change in the dynamics of the $P$. antipodarum population was evident during our 14-year field investigation. After an exponential growth, the introduced population strongly declined before the last monitoring period and the snail abundance was about 14-fold lower compared to its initial abundance. Given the long history of the P. antipodarum invasion in France [over 100 years, first recorded in 1912 (Lucas, 1965)], we cannot know whether the dynamics we documented in Le Petit Hermitage reflect periodic cycling of a long-established population (Ricklefs \& Miller, 2005), or a post-invasion "boom and bust," similar to that described for P. antipodarum in a North American California stream, 7 years after its first report there (Moore et al., 2012). According to relatively short-term ( $<5$ years) demographic studies, population dynamics of $P$. antipodarum in invaded ranges can be unstable, with unexplained rapid increases and sudden extinctions (e.g., Dorgelo, 1987; McMillan, 1990; Dahl \& Winter, 1993; Levri et al., 2008; Cross et al., 2011; Dorgelo et al., 2014). These extinctions, for which the causes remain unknown, occur despite the generally large physiological tolerance characterizing the small number of clones that have invaded most of the world's continents, particularly the generalist clone (haplotype t) from European fresh waters (e.g., Hughes, 1996; Jacobsen \& Forbes, 1997; Städler et al., 2005; Hoy et al., 2012), which probably occurs in our study site.

In Le Petit Hermitage, the absence of male P. antipodarum indicates that the population was exclusively composed of parthenogenetic females. The lack of sexual reproduction is consistent with what is seen for introduced $P$. antipodarum from Europe, Australia, and America, where males are rare or completely absent (e.g., Wallace, 1978, 1985; Hughes, 1996; Schreiber et al., 1998; Gérard et al., 2003; Gaino et al., 2008; McKenzie et al., 2013; Collado, 2014).

The number of embryos per female P. antipodarum in Le Petit Hermitage 
increased from March to May in each year, and also increased with snail size, as previously demonstrated (e.g., Winterbourn, 1970; Gérard \& Poullain, 2005; Gaino et al., 2008; McKenzie et al., 2013). Females were reproductively mature at shell height from 2.5 to $3.0 \mathrm{~mm}$, with up to 74 embryos in the largest females. These results are also consistent with observations for other introduced populations, which mature at size between 2.5 and $3.5 \mathrm{~mm}$, and have maximum brood size ranging from 60 to 89 embryos (e.g., Strzelec \& Serafinski, 1996; Gaino et al., 2008; McKenzie et al., 2013).

Based on the size-frequency distributions (Supplementary Fig.), both adult and newly recruited, growing $P$. antipodarum were present throughout the year, but without obvious, constrained periods where most recruitment occurred. In general, parthenogenetic forms of $P$. antipodarum produce offspring throughout the year, with seasonal fluctuations in reproductive output depending on the clonal population considered and environmental conditions such as temperature, hardness (dissolved calcium), phosphorus level, food availability, and population density (e.g., Winterbourn, 1970; Dussart, 1977; Dahl \& Winter, 1993; Schreiber et al., 1998; Neiman, 2006, 2013; Tibbets et al., 2010; McKenzie et al., 2013). Females in Le Petit Hermitage had a higher fecundity in 2013 when population densities were low (from 12 to 48 snails sampled per month) than in 2002 and 2004 when densities were very high (from 1,623 to 2,993 snails per month), although no significant correlation was found between monthly embryo number per adult female and snail abundance. If the high fecundity in 2013 represents fecundity during the last monitoring period (2009-2012), it would indicate that higher mortality rates, not lower birth rates, are what drove population density down. However, it is possible that 2013 represented recently increased individual fecundity preceding the beginning of a new population increase. According to Neiman (2006), a nearly twofold increase in the embryo number per female was observed in low versus high density populations maintained in the laboratory with similar food availability, suggesting that reproductive output may be influenced by intraspecific competition. In contrast, the reproductive output of $P$. antipodarum was much higher in high versus low density conditions in other experiments with no food limitation (Neiman et al., 2013), as also observed in the Italian Topino River (Gaino et al., 2008). Thus, further investigations are needed for a more comprehensive view of the complex connections between environmental quality, resource availability, density, and fecundity of parthenogenetic females, and how they may influence the 
population dynamics of $P$. antipodarum.

\section{What possible environmental changes may influence the dynamics of $P$. antipodarum?}

Despite the difficulty of identifying the causes of $P$. antipodarum population decline in Le Petit Hermitage, we explore two potential explanations.

First, the snail abundance may have been negatively influenced by changing abiotic conditions, such as the substantial decrease in water temperature and depth. Indeed, mean water temperature decreased about $3^{\circ} \mathrm{C}$ between the first and the last monthly monitoring periods (2000-2001 and 2009-2012), and very low winter temperatures $\left(0-5^{\circ} \mathrm{C}\right)$ were frequently observed during 2009-2012 (vs. 2000-2001). Such temperatures $\left(0-5^{\circ} \mathrm{C}\right)$ have been associated with lower performance and population densities of $P$. antipodarum in a Danish estuary (Europe) and the Silver Creek watershed (Idaho, USA) (Siegismund \& Hylleberg, 1987; Moffitt \& James, 2012a, b). In fact, temperature is generally considered to drive $P$. antipodarum dynamics even if temperature tolerance may vary between invasive clones (Gangloff, 1998; Kerans et al., 2005). Temperature is one of the most significant physicochemical variables positively related to $P$. antipodarum density, as demonstrated in 15 European sites from North West England and the French Bay of Mont St. Michel (including Le Petit Hermitage) (Dussart, 1977; Gérard \& Dussart, 2003) and in two California (USA) lakes (Bennett et al., 2015). Hence, it is possible that the temperature decrease explains the substantial decrease in $P$. antipodarum population abundance observed over the 14-year time period.

In addition to the temperature decrease, the water depth decreased by almost half from 2000-2001 to 2009-2012, resulting in a reduced water volume and a more restricted habitat area. In general, the increase in predator pressure and interspecific competition related to the restricted habitat size during drought leads to the elimination of most freshwater gastropods, and new generations typically appear after the water level rises again (Dudgeon, 1982; Gérard, 2001). In small Mediterranean streams characterized by seasonal droughts and floods, $P$. antipodarum populations are generally incapable of achieving very high densities, and this has been attributed mainly to harsh hydrologic conditions (Múrria et al., 2008). In conditions of much deeper depths $(\geq 10 \mathrm{~m}$ ), as in the North American Great Lakes, the density of $P$. antipodarum is influenced by water depth and highest densities occurred 
between 15 and $25 \mathrm{~m}$, no individuals being detected at less than $13 \mathrm{~m}$ and at more than $40 \mathrm{~m}$ (Levri et al., 2008). Hence, it is possible that in the shallow studied stream, the water depth (habitat area) decrease may have combined with lower temperatures to negatively influence $P$. antipodarum abundance, explaining its longer-term decline.

Secondly, it is possible that $P$. antipodarum may have been negatively affected by sphaeriid bivalves, or vice versa. Some studies (e.g., Kerans et al., 2005; Hall et al., 2006; Moore et al., 2012) have shown negative interactions between $P$. antipodarum density (and/or biomass) and those of native macroinvertebrates. In a North American California stream for instance, as $P$. antipodarum populations rose and fell, the abundance of native grazing herbivores crashed and then recovered (Moore et al., 2012). In our study, sphaeriid bivalves were rarely recorded during 2000-2001, corresponding to the period of increasing abundance of $P$. antipodarum. Then, sphaeriid abundance rapidly increased about 27-fold from 2002 to 2004, and high abundance was maintained in 2009-2012 and until the end of the study in 2013, coinciding with the decline of the $P$. antipodarum population. Even if no direct relationship was found between the abundance of Sphaeriidae and $P$. antipodarum, the increase of Sphaeriidae may have amplified the decline of $P$. antipodarum or may have resulted from the decline. Indeed, competitive interactions both for space and nutrients probably occur between them, given their great ecological and physiological similarities. Occurring in a great variety of lotic and lentic waters, Sphaeriidae inhabit the bottom (mud, sand) or bury in the substratum, and often climb up plants (Boycott, 1936; Dussart, 1979; Holopainen \& Jónasson, 1989; Dillon, 2004; Korniushin, 2007), as is also observed for P. antipodarum (Alonso \& Castro-Díez, 2008, 2012 for reviews). To feed, Sphaeriidae filter phytoplankton, bacteria, and particulate organic matter from the water column (Vaughn \& Hakenkamps, 2001; Dillon, 2004; Korniushin, 2007 for reviews). Interestingly and unlike most other bivalves, they also remove bacteria and organic detritus from the sediment by filtering interstitial water and pedal deposit feeding (i.e., a form of deposit feeding using cilia on the foot to collect buried organic matter) (Vaughn \& Hakenkamp, 2001 for review). P. antipodarum is a generalist feeder, simultaneously a deposit-feeder, grazer and detritivore, which uses periphytic algae (e.g., green algae, diatoms), bacteria, and detritus, and thus, the same resources as many other macroinvertebrates found in the French stream, including Sphaeriidae (Fenchel, 1975; Haynes \& Taylor, 1984; Schreiber et al., 1998; Kerans et al., 2005). Because food limitation is shown to be a 
primary source of negative density-dependence for $P$. antipodarum (Fenchel, 1975; Neiman et al., 2013), potential decrease of resource availability (not only food but also space) possibly induced by the increased abundance of Sphaeriidae may have contributed to the decline of P. antipodarum in Le Petit Hermitage. Hence, further studies are warranted to carefully examine the extent to which competition occurs between $P$. antipodarum and sphaeriids. Such studies might use biomass as a currency, instead of abundance, which could be important given that the sizes of these taxa can substantially differ (e.g., P. antipodarum is usually $\sim 2-5 \mathrm{~mm}$ length, whereas $S$. corneum can be 10-12 mm) (Glöer \& Meier-Brook, 1994).

We may explain the increased abundance of Sphaeriidae by them responding positively to changing environmental conditions, as is documented elsewhere. For instance, the great temporal fluctuations of Sphaeriidae (both Pisidium and Sphaerium) observed in a Danish Lake through a 34-year investigation were possibly due to eutrophication and food availability (Holopainen \& Jónasson, 1989). In Le Petit Hermitage, the increase of Sphaeriidae may be related to the substantial decrease of water depth because sphaeriid density was negatively influenced by water depth. More precisely, the rapid increase of sphaeriid abundance from 2002 to 2004 (about 27-fold), followed by consistently high abundance from 2009 to the end of the study, coincided with the lower water levels in Le Petit Hermitage (29 cm in 2002-2004 and $25 \mathrm{~cm}$ in 2009-2012 vs $41 \mathrm{~cm}$ in 2000-2001). Our results are consistent with the gradual reduction of Pisidium spp. abundance in the North American Ottawa River as depth increased beyond $50 \mathrm{~cm}$ (Kilgour \& Mackie, 1988). Moreover, Sphaeriidae can survive both temporary air exposure and freezing of the sediment they inhabit (Jurkiewicz-Karnkowska \& Zbikowski, 2004; Kubíková et al., 2011), yet may perform poorly at increased temperatures [e.g., the declines of Pisidium amnicum in the French Saône and Iberian Minho Rivers during heat waves (Mouthon \& Daufresne, 2008; Sousa et al., 2011)]. This all suggests that the substantially lower mean and minimum water temperatures and lower depths may have favored the population performance of Sphaeriidae in Le Petit Hermitage, and disfavored the population performance of $P$. antipodarum.

To conclude, both water temperature and depth decrease, and competitive interactions between $P$. antipodarum and Sphaeriidae may contribute to explain the longer-term decline of $P$. antipodarum in Le Petit Hermitage. Other environmental factors, not studied here, may have also contributed to 
this decline. For instance, microcystins (hepatotoxic cyanotoxins) known to induce the decline of molluscan assemblages in stagnant waters subject to recurrent cyanobacterial blooms (e.g., Gérard et al., 2008) were previously detected in tissues of $P$. antipodarum from Le Petit Hermitage despite the absence of cyanobacteria (Gérard et al., 2009). The large, long-term population drop of $P$. antipodarum in Le Petit Hermitage is similar in magnitude to the decrease documented by Moore et al. (2012) for invasive $P$. antipodarum in a North American California stream. Although the drivers of that population crash are also not known, the collapse strongly influenced the impacts of the invasive snail on the surrounding ecosystem (Moore et al., 2012). The extent to which such strong fluctuations in population size and impacts occur for P. antipodarum more broadly in Europe is unknown given the lack of other long-term data sets on the abundance of this invasive species.

\section{Temporal fluctuations of Aporocotylid sp. I prevalence in $P$. antipodarum and number of infected snails}

Despite the decreasing abundance of P. antipodarum in Le Petit Hermitage, the aporocotylid prevalence did not significantly vary between the monitoring periods and appeared to remain stable over the 14-year study with a mean prevalence of $0.09 \%$ and a maximal monthly prevalence of $1.52 \%$. Both the occurrence of a single parasite species in the introduced mudsnail and the low prevalence of this parasite are in accordance with the Enemy Release Hypothesis, namely that the success of introduced species is at least partly driven by them having relatively low levels of overall parasitism (Torchin et al., 2003). The low prevalence of Aporocotylid sp. I in Le Petit Hermitage is also consistent with that observed in Poland (Zbikowski \& Zbikowska, 2009). Interestingly, this specific parasite (Aporocotylid sp. I) also has similarly low prevalence in populations of $P$. antipodarum in the native range (New Zealand) (Gérard et al., 2017). As Gérard et al. (2017) noted, this pattern is also consistent with the general pattern characterizing invasive parasites, where, for those few parasites that make it to an invaded range with their host, there is no general tendency for prevalence to change compared to that in the native range (Torchin et al., 2003). However, the persistence of this host-parasite association in Le Petit Hermitage may be threatened, at least in the long term, if there is a real decline of the host population. Indeed, as the snail host population strongly declined during the study period, so did the number of snails infected by Aporocotylid sp. I in Le Petit Hermitage (15 in 2000-2001, nine in 2002-2004, one in 2009-2012, and no infected snails in 
2013). Although no infected P. antipodarum were detected after June 2009 [i.e., 10 years after the first record in the same region (Gérard et al., 2003)], we cannot infer that the parasite is no longer present. It is possible that the parasite is still present because the low abundance of the snail during that time period (2009-2013) translated into lower sample sizes compared with the early part of the temporal study (2000-2004). Hence, although we dissected 1,321 snails after June 2009 (from July 2009 to May 2013), the low overall prevalence of the parasite $(0.09 \%)$ means that we had a $30 \%$ chance of missing it $\left[(1-0.0009)^{1321}=0.30\right]$. In any case, the population size of Aporocotylid sp. I decreased (assuming the river site reflected the broader population) and it remains an open question how much of this drop was driven by the decline in P. antipodarum abundance, or by other factors, including those involving the parasite's unknown final host fish in New Zealand, as well as in Europe (Gérard et al., 2017).

\section{Conclusion}

In summary, we document a substantial population decline for the invasive $P$. antipodarum in a French stream, indicating that the ecological impacts of this invader have changed over time. This population decline was potentially driven directly or indirectly by documented environmental changes in water temperature and depth and competitive interactions with sphaeriid clams. Further studies are needed to (i) confirm what mechanisms underlie negative density-dependence in P. antipodarum, (ii) determine whether the population decline of $P$. antipodarum is more widespread, and (iii) understand how the population collapse has influenced the impacts of this invader on species in the surrounding communities, including the dynamics of its "co-invasive" aporocotylid parasite.

\section{Acknowledgements}

We thank Valérie Briand for bibliographical assistance.

Compliance with ethical standards

Conflict of interest All of the authors read and approved the paper that has not been published previously nor is it being considered by any other peer-reviewed journal. The authors declare that there are no conflicts of interest.

\section{Electronic supplementary material}


Below is the link to the electronic supplementary material.

\section{Supplemental Table}

Physicochemical characteristics of the French stream "Le Petit Hermitage" measured in May 2003 (DOCX $17 \mathrm{~kb}$ )

\section{Supplementary Fig.}

Relative size-frequency distributions of $P$. antipodarum in different months from June 2000 to September 2004 (a) and from April 2009 to May 2013 (b) in the French stream "Le Petit Hermitage" (size classes in mm, relative abundance from 0 to $100 \%$ with $10 \%$-step graduation). Sample size is indicated for each month (PDF $110 \mathrm{~kb}$ )

\section{References}

Alonso, A. \& P. Castro-Díez, 2008. What explains the invading success of the aquatic mud snail Potamopyrgus antipodarum (Hydrobiidae, Mollusca)? Hydrobiologia 614: 107-116.

Alonso, A. \& P. Castro-Díez, 2012. The exotic aquatic mud snail Potamopyrgus antipodarum (Hydrobiidae, Mollusca): state of the art of a worldwide invasion. Aquatic Sciences 74: 375-383.

Bennett, D. M., T. L. Dudley, S. D. Cooper \& S. S. Sweet, 2015. Ecology of the invasive New Zealand mud snail, Potamopyrgus antipodarum (Hydrobiidae), in a mediterranean-climate stream system. Hydrobiologia 746: 375-399.

Blanc, A. \& C. Gérard, 2001. Etude préliminaire de la malacofaune de deux hydrosystèmes interconnectés dans une zone humide. International Journal of Limnology 37: 277-280.

Boycott, A. E., 1936. The habitats of freshwater mollusca in Britain. Journal of Animal Ecology 5: 116-186.

Bush, A. O., K. D. Lafferty, J. M. Lotz \& A. W. Shostak, 1997. 
Parasitology meets ecology on its own terms: Margolis et al. revisited. Journal of Parasitology 83: 575-583.

Clément, J.-C., G. Pinay \& P. Marmonier, 2002. Seasonal dynamics of denitrification along toposequences in three different riparian wetlands. Journal of Environmental Quality 31: 1025-1037.

Collado, G. A., 2014. Out of New Zealand: molecular identification of the highly invasive freshwater mollusk Potamopyrgus antipodarum (Gray, 1843) in South America. Zoological Studies 53: 70.

Cross, W. F., C. V. Baxter, K. C. Donner, E. J. Rozi-Marshall, T. A. Kennedy, R. O. Hall, H. A. Wellard Kelly \& R. S. Rogers, 2011. Ecosystem ecology meets adaptive management: food web response to a controlled flood on the Colorado River, Glen Canyon. Ecological Applications 21: 2016-2033.

Dahl, A. \& L. B. Winter, 1993. Life-history and growth of the prosobranch snail Potamopyrgus jenkinsi in Lake Esrom, Denmark. Verhandlungen des Internationalen Verein Limnologie 25: 582-586.

Dillon, R. T., 2004. The Ecology of Freshwater Molluscs. Cambridge University Press, Cambridge.

Dorgelo, J., 1987. Density fluctuations in populations (1982-1986) and biological observations of Potamopyrgus jenkinsi in two trophically differing lakes. Hydrobiological Bulletin 21: 95-110.

Dorgelo, J., H. G. van der Geest \& E. R. Hunting, 2014. Dynamics of natural populations of the detritivorous mudsnail Potamopyrgus antipodarum (Gray) (Hydrobiidae) in two interconnected Lakes differing in trophic state. SpringerPlus 3: 736.

Dudgeon, D., 1983. The effects of water fluctuations on a gently shelving marginal zone of Plover Cove Reservoir, Hong Kong. Archiv für Hydrobiologie 65: 163-196.

AQ3

Duft, M., C. Schmitt, J. Bachmann, C. Brandelik, U. Schulte-Oehlmann \& J. Oehlmann, 2007. Prosobranch snails as test organisms for the 
assessment of endocrine active chemicals - an overview and a guideline proposal for a reproduction test with the freshwater mudsnail Potamopyrgus antipodarum. Ecotoxicology 16: 169-182.

Dussart, G. B. J., 1976. The ecology of freshwater mollusks in North West England in relation to water chemistry. Journal of Molluscan Studies 42: 181-198.

Dussart, G. B. J., 1977. The ecology of Potamopyrgus jenkinsi (Smith) in North West England with a note on Marstoniopsis scholtzi (Schmidt). Journal of Molluscan Studies 43: 208-216.

Dussart, G. B. J., 1979. Sphaerium corneum (L.) and Pisidium spp. Pfeiffer - the ecology of freshwater bivalve molluscs in relation with water chemistry. Journal of Molluscan Studies 45: 19-34.

Fenchel, T., 1975. Factors determining the distribution patterns of mud snails (Hydrobiidae). Oecologia 20: 1-17.

Gaino, E., F. Scoccia, T. Lancioni \& A. Ludovisi, 2008. The invader mudsnail Potamopyrgus antipodarum in the Tiiber River basin (Central Italy). Italian Journal of Zoology 75: 1-9.

Gangloff, M. M., 1998. The New Zealand mud snail in Western North America. Aquatic Nuisance Species Digest 2: 25-30.

Gérard, C., 1997. Importance du parasitisme dans la communauté de Gastéropodes de l'étang de Combourg (Bretagne, France). Parasite 4: $49-54$.

Gérard, C., 2001. Structure and temporal variation of trematode and gastropod communities in a freshwater ecosystem. Parasite 8: 275-287.

Gérard, C. \& G. B. J. Dussart, 2003. Invader and invaded - colonization by, and of, Potamopyrgus antipodarum Gray (Mollusca, Hydrobiidae). BCPC Symposium Proceedings NO. 80: Slugs \& Snails: Agricultural, Veterinary \& Environmental Perspectives: 281-286.

Gérard, C. \& J. Le Lannic, 2003. Establishment of a new host-parasite association between the introduced invasive species Potamopyrgus 
antipodarum (Smith) (Gastropoda) and Sanguinicola sp. Plehn (Trematoda) in Europe. Journal of Zoology 261: 213-216.

Gérard, C. \& V. Poullain, 2005. Variation in the response of the invasive species Potamopyrgus antipodarum (Smith) to natural (cyanobacterial toxin) and anthropogenic (herbicide atrazine) stressors. Environmental Pollution 138: 28-33.

Gérard, C., A. Blanc \& K. Costil, 2003. Potamopyrgus antipodarum (Mollusca: Hydrobiidae) in continental aquatic gastropod communities: impact of salinity on trematode parasitism. Hydrobiologia 493: 167-172.

Gérard, C., A. Carpentier \& J.-M. Paillisson, 2008. Long-term dynamics and community structure of freshwater gastropods exposed to parasitism and other environmental stressors. Freshwater Biology 53: 1-21.

Gérard, C., V. Poullain, E. Lance, A. Acou, L. Brient \& A. Carpentier, 2009. Ecological impacts of toxic cyanobacteria on community structure and microcystin bioaccumulation of freshwater molluscs. Environmental Pollution 157: 609-617.

Gérard, C., O. Miura, J. Lorda, T. H. Cribb, M. J. Nolan \& R. F. Hechinger, 2017. A native-range source for a persistent trematode parasite of the exotic New Zealand mudsnail (Potamopyrgus antipodarum) in France. Hydrobiologia 785: 115-126.

Glöer, P. \& C. Meier-Brook, 1994. Süsswassermollusken. Deutscher Jugendbund für Naturbeobachtung, Hamburg.

Gray, J. E., 1843. Fauna of New Zealand: materials towards a fauna of New Zealand, Auckland Island, and Chatham Islands. In Dieffenbach, E. (ed.), Travels in New Zealand: with Contributions to the Geography, Geology, Botany, and Natural History of that Country (Volume 2). John Murray, London: 177-295.

Gruau, G., A. Dia, G. Olivié-Lauquet, M. Davranche \& G. Pinay, 2004. Controls on the distribution of rare earth elements in shallow groundwater. Water Research 38: 3576-3586.

Gust, M., T. Buronfosse, O. Geffard, M. Coquery, R. Mons, L. Giamberini 
\& J. Garric, 2011. Comprehensive biological effects of a complex field poly-metallic pollution gradient on the New Zealand mudsnail Potamopyrgus antipodarum (Gray). Aquatic Toxicology 101: 100-108.

Hall, R. O., M. F. Dybdahl \& M. C. Vanderloop, 2006. Extremely high secondary production of introduced snails in rivers. Ecological Applications 16: 1121-1131.

Haynes, A. \& B. Taylor, 1984. Food finding and food preference in Potamopyrgus jenkinsi. Archiv für Hydrobiologie 100: 479-491.

Hechinger, R. F., 2012. Faunal survey and identification key for the trematodes (Platyhelminthes: Digenea) infecting Potamopyrgus antipodarum (Gastropoda: Hydrobiidae) as first intermediate host. Zootaxa 3418: 1-27.

Holopainen, I. J. \& P. M. Jónasson, 1989. Bathymetric distribution and abundance of Pisidium (Bivalvia: Sphaeriidae) in Lake Esrom, Denmark from 1954 to 1988. Oikos 55: 324-334.

Hoy, M. \& R. J. Rodriguez, 2013. Intragenomic sequence variation at the ITS1-ITS2 region and at the $18 \mathrm{~S}$ and $28 \mathrm{~S}$ nuclear ribosomal DNA genes of the New Zealand mud snail, Potamopyrgus antipodarum (Hydrobiidae: Mollusca). Journal of Molluscan Studies 79: 205-217.

Hoy, M., B. L. Boese, L. Taylor, D. Reusser \& R. Rodriguez, 2012. Salinity adaptation of the invasive New Zealand mud snail (Potamopyrgus antipodarum) in the Columbia River estuary (Pacific Northwest, USA): physiological and molecular studies. Aquatic Ecology 46: 249-260.

Hughes, R. N., 1996. Evolutionary ecology of parthenogenentic strains of the prosobranch snail, Potamopyrgus antipodarum (Gray) (=P. jenkinsi (Smith)). Molluscan Reproduction in Malacological Review 6: 101-113.

Jacobsen, R. \& V. E. Forbes, 1997. Clonal variation in life-history traits and feeding rates in the gastropod, Potamopyrgus antipodarum: performance across a salinity gradient. Functional Ecology 11: 260-267.

Jurkiewicz-Karnkowska, E. \& J. Zbikowski, 2004. Long-term changes and spatial variability of mollusc communities in selected habitats within the 
dam reservoir (Włocławek reservoir, Vistula River, Central Poland). Polish Journal of Ecology 52: 491-503.

Kolar, C. S. \& D. M. Lodge, 2001. Progress in invasion biology: predicting invaders. Trends in Ecology \& Evolution 16: 199-204.

Kerans, B. L., M. F. Dybdahl, M. M. Gangloff \& J. E. Jannot, 2005. Potamopyrgus antipodarum: distribution, density, and effects on native macroinvertebrate assemblages in the Greater Yellowstone Ecosystem. Journal of the North American Benthological Society 24: 123-138.

Kilgour, B. \& G. Mackie, 1988. Factors affecting the distribution of sphaeriid bivalves in Britannia Bay of the Ottawa River. Nautilus 102: $73-77$.

Korniushin, A. V., 2007. Non-unionid freshwater bivalves (Sphaeriidae, Corbiculidae, Dreissenidae) of North American fauna. Vestnik zoologii 41: $13-22$.

Kubíková, L., O. Simon \& K. Fricová, 2011. The occurrence of Pisidium species (Bivalvia: Sphaeriidae) in oligotrophic springs of the Blanice River catchment (Czech Republic) in relation to ecological conditions. Biologia 66: 299-307.

Lafferty, K. D., 1993. Effects of parasitic castration on growth, reproduction and population dynamics of the marine snail Cerithidea californica. Marine Ecology Progress Series 96: 229-237.

Lefebvre, S., P. Marmonier \& G. Pinay, 2004. Stream regulation and nitrogen dynamics in sediment interstices: comparison of natural and straightened sectors of a third-order stream. River Research and Applications 20: 499-512.

Lenth, R., 2016. Least-squares means: the R package lsmeans. Journal of Statistical Software 69: 1-33.

Levri, E. P. \& T. J. Clark, 2015. Behavior in invasive New Zealand mud snails (Potamopyrgus antipodarum) is related to source population. Biological Invasions 17: 497-506. 
Levri, E. P., R. M. Dermott, S. J. Lunnen, A. A. Kelly \& T. Ladson, 2008. The distribution of the invasive New Zealand mud snail (Potamopyrgus antipodarum) in Lake Ontario. Aquatic Ecosystem Health \& Management 11: 412-421.

Lucas, A., 1965. Progrès récents en Europe d'une espèce envahissante : Hydrobia jenkinsi (E. A. Smith), mollusque gastéropode. PhD Thesis, University of Rennes.

McKenzie, V. J., W. E. Hall \& R. P. Gulranick, 2013. New Zealand mud snail (Potamopyrgus antipodarum) in Boulder Creeck, Colorado: environmental factors associated with fecundity of a parthenogenic invader. Canadian Journal of Zoology 91: 30-36.

McMillan, N., 1990. The history of alien freshwater mollusca in North-West England. Naturalist 115: 123-132.

Moffitt, C. M. \& C. A. James, 2012a. Response of New Zealand mudsnails Potamopyrgus antipodarum to freezing and near-freezing fluctuating water temperatures. Freshwater Science 31: 1035-1041.

Moffitt, C. M. \& C. A. James, 2012b. Dynamics of Potamopyrgus antipodarum infestations and seasonal water temperatures in a heavily used recreational watershed in intermountain North America. Aquatic Invasions 7: 193-202.

Moore, J. W., D. B. Herbst, W. N. Heady \& S. M. Carlson, 2012. Stream community and ecosystem responses to the boom and bust of an invading snail. Biological Invasions 14: 2435-2446.

Mouthon, J. \& M. Daufresne, 2008. Population dynamics and life cycle of Pisidium amnicum (Müller) (Bivalvia: Sphaeriidae) and Valvata piscinalis (Müller) (Gastropoda: Prosobranchia) in the Saône river, a nine-year study. International Journal of Limnology 44: 241-251.

Múrria, C., N. Bonada \& N. Prat, 2008. Effects of the invasive species Potamopyrgus antipodarum (Hydrobiidae, Mollusca) on community structure in a small Mediterranean stream. Fundamental and Applied Limnology/Archiv für Hydrobiologie 171: 131-143. 
Negovetich, N. J. \& G. W. Esch, 2008. Life history cost of trematode infection in Helisoma anceps using mark-recapture in Charlie's pond. Journal of Parasitology 94: 314-325.

Neiman, M., 2006. Embryo production in a parthenogenetic snail (Potamopyrgus antipodarum) is negatively affected by the presence of other parthenogens. Invertebrate Biology 125: 45-50.

Neiman, M., D. Warren, B. Rasmussen \& S. Zhang, 2013. Complex consequences of increased density for reproductive output in an invasive freshwater snail. Evolutionary Ecology 27: 1117-1127.

Newcombe, R. G., 1998. Two-sided confidence intervals for the single proportion: comparison of seven methods. Statistics in Medicine 17: 857-872.

Pinheiro, J., D. Bates, S. DebRoy, D. Sarkar \& R Core Team, 2017. nlme: Linear and Nonlinear Mixed Effects Models. R package version 3.1-131.

R Core Team, 2014. R: A Language and Environment for Statistical Computing. R Foundation for Statistical Computing, Vienna, Austria. http://www.R-project.org/.

Ricklefs, R. E. \& G. L. Miller, 2005. Ecologie ( $4{ }^{\text {ème }}$ Edition). Editions De Boeck.

Ruppert, K., C. Geiß, S. Ostermann, C. Theis \& J. Oehlmann, 2016. Comparative sensitivity of juvenile and adult Potamopyrgus antipodarum (Mollusca: Hydrobiidae) under chronic exposure to cadmium and tributyltin. Journal of Environmental Science and Health, Part A. 51: 736-743.

Schreiber, E. S. G., A. Glaister, G. P. Quinn \& P. S. Lake, 1998. Life-history and population dynamics of the exotic snail Potamopyrgus antipodarum (Prosobranchia: Hydrobiidae) in lake Purrumbete, Victoria, Australia. Marine and Freshwater Research 49: 73-78.

Siegismund, H. R. \& J. Hylleberg, 1987. Dispersal-mediated coexistence of mud snails (Hydrobiidae) in an estuary. Marine Biology 94: 395-402. 
Simberloff, D. \& L. Gibbons, 2004. Now you see them, now you don't! Population crashes of established introduced species. Biological Invasions 6: $161-172$.

Simberloff, D., 2013. Invasive Species: What Everyone Needs to Know. Oxford University Press, Oxford.

Sousa, R., M. Ilarri, A. T. Souza, C. Antunes \& L. Guilhermino, 2011. Rapid decline of the greater European peaclam at the periphery of its distribution. International Journal of Limnology 47: 211-219.

Städler, T., M. Frye, M. Neiman \& C. M. Lively, 2005. Mitochondrial haplotypes and the New Zealand origin of clonal European Potamopyrgus, an invasive aquatic snail. Molecular Ecology 14: 2465-2473.

Strayer, D. L., V. T. Eviner, J. M. Jeschke \& M. L. Pace, 2006. Understanding the long-term effects of species invasions. Trends in Ecology \& Evolution 21: 645-651.

Strzelec, M. \& W. Serafinski, 1996. Population ecology of Potamopyrgus antipodarum (Gray, 1843) in a recently colonized area: Upper Silesia (Southern Poland) (Gastropoda: Prosobranchia: Hydrobiidae).

Malakologische Abhandlungen Staatlichen Museum für Tierkunde Dresden 18: $75-82$.

Strzelec, M., 1999. Effect of elevated water temperature on the occurrence of freshwater snails in the Rybnik Dam Reservoir (Upper Silesia, Poland). Folia Malacologica 7: 93-98.

Tibbets, T. M., A. C. Krist, R. O. Hall Jr. \& L. A. Riley, 2010. Phosphorusmediated changes in life history traits of the invasive New Zealand mudsnail (Potamopyrgus antipodarum). Oecologia 163: 549-559.

Torchin, M. E., K. D. Lafferty, A. P. Dobson, V. J. McKenzie \& A. M. Kuris, 2003. Introduced species and their missing parasites. Nature 421: 628-630.

Vaughn, C. C. \& C. C. Hakenkamp, 2001. The functional role of burrowing bivalves in freshwater ecosystems. Freshwater Biology 46: 1431-1446. 
Wallace, C., 1978. Notes on the distribution of sex and shell characters in some australian populations of Potamopyrgus (Gastropoda : Hydrobiidae). Journal of the Malacological Society of Australia 4: 71-76.

Wallace, C., 1985. On the distribution of the sexes of Potamopyrgus jenkinsi (Smith). Journal of Molluscan Studies 51: 290-296.

Wilke, T., M. Haase, R. Hershler, H. P. Liu, B. Misof \& W. Ponder, 2013. Pushing short DNA fragments to the limit: phylogenetic relationships of 'hydrobioid' gastropods (Caenogastropoda: Rissooidea). Molecular Phylogenetics and Evolution 66: 715-736.

Winterbourn, M. J., 1970. Population studies on the New Zealand freshwater gastropod, Potamopyrgus antipodarum (Gray). Proceedings of the Malacological Society of London 39: 139-149.

Zbikowski, J. \& E. Zbikowska, 2009. Invaders of an invader - Trematodes in Potamopyrgus antipodarum in Poland. Journal of Invertebrate Pathology 101: 67-70.

Zielske, S., M. Glaubrecht \& M. Haase, 2011. Origin and radiation of rissooidean gastropods (Caenogastropoda) in ancient lakes of Sulawesi. Zoologica Scripta 40: 221-237. 